\title{
Reactive oxygen species induce injury of the intestinal epithelium during hyperoxia
}

\author{
MIN ZHAO ${ }^{1}$, SHIMIAO TANG ${ }^{1}$, JUNCHI XIN ${ }^{1},{\text { YINGLIANG } \text { WEI }^{2} \text { and DONGYAN LIU }}^{1}$ \\ ${ }^{1}$ Medical Research Center and ${ }^{2}$ Department of Orthopaedic Surgery, Shengjing Hospital, \\ China Medical University, Shenyang, Liaoning 110000, P.R. China
}

Received September 8, 2016; Accepted October 27, 2017

DOI: $10.3892 /$ ijmm.2017.3247

\begin{abstract}
Long-term therapeutic hyperoxia may exert serious toxic effects on intestinal epithelial cells in vitro and in vivo. The aim of the present study was to investigate the cause of this intestinal injury under conditions of hyperoxia. Caco-2 cells were treated with different concentrations of hydrogen peroxide $\left(\mathrm{H}_{2} \mathrm{O}_{2}\right)$ and $85 \%$ hyperoxia for $24 \mathrm{~h}$. Higher rates of injury of Caco- 2 cells were observed in the hyperoxia and $\mathrm{H}_{2} \mathrm{O}_{2}$ groups compared with the control group. The reactive oxygen species (ROS) level of the hyperoxia group was significantly higher compared with that of the $400 \mu \mathrm{M} \mathrm{H}_{2} \mathrm{O}_{2}$ group. The protein and gene levels of RelA, RelB, hypoxia-inducible factor-1 $\alpha$, tumor necrosis factor- $\alpha$ and apoptosis signal-regulating kinase 1 were significantly higher in the hyperoxia and $\mathrm{H}_{2} \mathrm{O}_{2}$ groups compared with those in the control group. In conclusion, during hyperoxia, intestinal epithelial cells were destroyed and the levels of ROS were increased. Therefore, ROS may play an important role in intestinal injury in a hyperoxic environment.
\end{abstract}

\section{Introduction}

Hyperoxia is an indispensable therapeutic measure in the clinical intensive care of certain neonatal conditions; however, long-term therapeutic hyperoxia may exert serious toxic effects on several organs. Early exposure to hyperoxia results in progressive lung disease in premature infants (1), and hyperoxia may induce bronchopulmonary dysplasia,

Correspondence to: Dr Dongyan Liu, Medical Research Center, Shengjing Hospital, China Medical University, 36 Sanhao Street, Heping, Shenyang, Liaoning 110000, P.R. China

E-mail: liudy19701010@sina.com

Abbreviations: ROS, reactive oxygen species; $\mathrm{H}_{2} \mathrm{O}_{2}$, hydrogen peroxide; TNF- $\alpha$, tumor necrosis factor- $\alpha$; ASK1, apoptosis signal-regulating kinase 1; MAP, mitogen-activated protein; JNK, c-Jun N-terminal kinase; HIF-1 $\alpha$, hypoxia-inducible factor- $1 \alpha$

Key words: hyperoxia, reactive oxygen species, hydrogen peroxide, nuclear factor- $\kappa \mathrm{B}$, apoptosis signal-regulating kinase 1 , tumor necrosis factor- $\alpha$, hypoxia-inducible factor- $1 \alpha$ inhibit cell proliferation and decrease cell viability (2). Hyperoxia-induced epithelial disruption, such as weakening of tight junctions and induction of a pro-inflammatory environment, is the main cause of hyperoxia-related organ injury (3). Recently, the clinical use of hyperoxia was reported to exacerbate organ injury by increasing the production of reactive oxygen species (ROS) (4). ROS include superoxide radicals and hydrogen peroxide $\left(\mathrm{H}_{2} \mathrm{O}_{2}\right)$, as well as its downstream products, such as peroxide and hydroxyl compounds. ROS affect cell viability, proliferation, differentiation, aging, apoptosis, and a number of physiological and pathological processes. ROS, primarily oxygen ions and $\mathrm{H}_{2} \mathrm{O}_{2}$, are produced in mitochondria (5). Under normal conditions in vivo, the generation and removal of ROS are in dynamic balance, and ROS are beneficial to the organism without causing harm. However, excess generation of ROS in epithelial cells is harmful. It has been reported that ROS coordinate the inflammatory response of tissues (6), and that $\mathrm{H}_{2} \mathrm{O}_{2}$ significantly reduces the activities of superoxide dismutase, glutathione peroxidase, catalase and lipase (7). When the intestinal mucosal barrier is damaged, intestinal mucosal Th1 cytokines, such as tumor necrosis factor (TNF)- $\alpha$ and interleukin (IL)-1, stimulate epithelial cells to produce ROS. TNF- $\alpha$ is a central mediator of the inflammatory response (8). ROS are cytotoxic, but they may also act as second messengers in intracellular signal transduction and control the action of several signaling pathways, including mitogen-activated protein kinases (MAPKs) (9). Apoptosis signal-regulating kinase 1 (ASK1) is a MAPKKK of the c-Jun $\mathrm{N}$-terminal kinase (JNK) and p38 MAPK pathways (9). ASK1 is a member of the MAPK family, and it plays an important role in the regulation of cellular apoptotic processes.

Additionally, MAPKs are known to be important for the transcriptional activation of nuclear factor (NF) $-\kappa B(10)$, which is a transcription factor that has been shown to be a central regulator of inflammatory response (11). The $\mathrm{NF}-\kappa \mathrm{B}$ family of transcription factors comprises 5 subunits, designated RelA (p65), RelB, c-Rel, p50 (NF- $\mathrm{BB} 1)$ and p52 $(\mathrm{NF}-\kappa \mathrm{B} 2)$. Hypoxia-inducible factor- $1 \alpha(\mathrm{HIF}-1 \alpha)$ is a key regulatory factor in the induction of the hypoxia gene and the repair of the cellular oxygen environment. HIF-1 $\alpha$ may also provide information on hypoxia induction and oxidative stress (12). Long-term treatment with hyperoxia may exert serious toxic effects on intestinal epithelial cells in vitro and in vivo (2,13-16). Therefore, the aim of the prsent study was 
to investigate the cause of intestinal injury during hyperoxia, and determine whether ROS generation is a main factor in intestinal injury under hyperoxic conditions.

\section{Materials and methods}

Cell culture. The human colon adenocarcinoma cell line Caco-2 was obtained from the Cell Biological Institute of Shanghai, Chinese Academy of Sciences (Shanghai, China). The cells were grown at $37^{\circ} \mathrm{C}$ in air and $5 \% \mathrm{CO}_{2}$ in sterile basal medium/DMEM-H (Sigma-Aldrich, Merck $\mathrm{KGaA}$, St. Louis, MO, USA) supplemented with $10 \%$ fetal bovine serum (Genview, Beijing, China), 1\% L-glutamine, $100 \mathrm{U} / \mathrm{ml}$ penicillin, $100 \mathrm{mg} / \mathrm{ml}$ streptomycin and $0.25 \mathrm{mg} / \mathrm{ml}$ amphotericin B. The culture medium was changed every 2-3 days. Prior to treatment, the cells were plated with fresh medium $\left(1 \times 10^{6}\right.$ cells $\left./ \mathrm{ml}\right)$ and cultured. On the second day after plating, Caco- 2 cells were incubated with different concentrations of $\mathrm{H}_{2} \mathrm{O}_{2}(100,200$ and $400 \mu \mathrm{M})$ and $85 \%$ oxygen [cells were cultured in three gas incubators (CB160; Binder $\mathrm{GmbH}$, Tuttlingen, Germany), with $85 \%$ oxygen and $5 \% \mathrm{CO}_{2}$ ] for $24 \mathrm{~h}$. A group of control cells received no treatment. Subsequently, the cultured cells were harvested, and the RNA and protein were extracted. All experiments were repeated 6-8 times.

Cell survival detected by MTT assay. Prior to treatment, cells were plated onto 96 -well microtiter plates with fresh medium and cultured at $37^{\circ} \mathrm{C}$ in air and $5 \% \mathrm{CO}_{2}$ for $24 \mathrm{~h}$. On the 2nd day after plating, the cells were treated with either 100, 200 or $400 \mu \mathrm{M} \mathrm{H}_{2} \mathrm{O}_{2}$, and $85 \%$ hyperoxia for $24 \mathrm{~h}$. Cells without any treatment were used as the control group. Subsequently, the cells were treated with $20 \mu \mathrm{MTT}$ for $4 \mathrm{~h}$ at $37^{\circ} \mathrm{C}$. The reactions were stopped by adding DMSO and the absorbance of each well at $450 \mathrm{~nm}$ was determined. Each sample was tested 6-8 times.

Determination of intracellular ROS level. Cells were plated at the same cell density in a culture flask. Cells without any treatment were used as the control group. Cells were treated with $\mathrm{H}_{2} \mathrm{O}_{2}(100,200$ and $400 \mu \mathrm{M})$ or $85 \%$ hyperoxia exposure for 24 h. ROS kits (E004; Nanjing Jiancheng Bioengineering Institute, Nanjing, China) were used to measure ROS levels (including $\mathrm{O}_{2}^{-}$and $\mathrm{H}_{2} \mathrm{O}_{2}$ ), according to the manufacturer's instructions. Dichloro-dihydro-fluorescein diacetate (DCFH-DA; $10 \mu \mathrm{M}$ ) was added to the cells and incubated for $30 \mathrm{~min}$ at $37^{\circ} \mathrm{C}$. The cells were then digested and suspended. The cell suspensions were centrifuged at $1,000 \mathrm{x} \mathrm{g}$ for $10 \mathrm{~min}$ and washed twice with phosphate-buffered saline (PBS). The cells were collected after centrifugation for fluorescence detection. Flow cytometry (FACSCalibur; Becton-Dickinson, San Jose, CA, USA) was used to measure fluorescence intensity. The positive area of DCFH-DA was ROS fluorescence intensity.

Immunohistochemistry analysis. The cells on coverslips that were treated with 100,200 and $400 \mu \mathrm{M} \mathrm{H}_{2} \mathrm{O}_{2}$, or $85 \%$ hyperoxia for $24 \mathrm{~h}$ were fixed with $4 \%$ paraformaldehyde. The cells were then treated with $10 \%$ goat serum for $30 \mathrm{~min}$ and incubated with mouse anti-human RelA (1:2,000; cat. no. SAB1404309) and rabbit anti-human RelB (1:2,000;

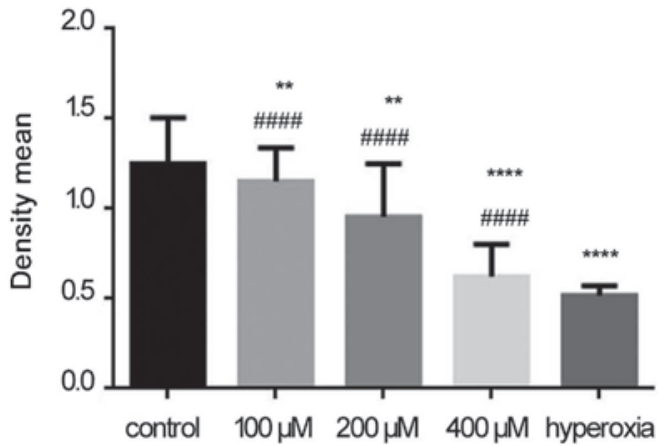

Figure 1. Survival of Caco-2 cells exposed to hydrogen peroxide $\left(\mathrm{H}_{2} \mathrm{O}_{2}\right)$ and hyperoxia. Compared with the control group, the cell survival rates in the hyperoxia and $\mathrm{H}_{2} \mathrm{O}_{2}$ groups were significantly lower. The survival rates of the $\mathrm{H}_{2} \mathrm{O}_{2}$ groups were higher compared with that of the hyperoxia group. The results are presented as mean \pm standard deviation. ${ }^{* *} \mathrm{P}<0.01$ and

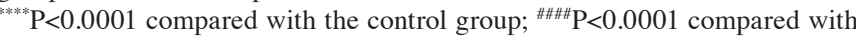
the $85 \%$ hyperoxia group, unpaired Student's t-test, $\mathrm{n} \geq 6$.

cat. no. SAB4300501) (both from Sigma-Aldrich, Merck $\mathrm{KGaA}$ ) (the antibody was diluted with PBS and 5\% bovine serum albumin) overnight at $4^{\circ} \mathrm{C}$, then incubated with a secondary antibody [biotin-labeled goat anti-mouse $\mathrm{IgG}$ (cat. no. SP-9002); biotin-labeled goat anti-rabbit IgG, (cat. no. SP-9001); ZSGB-BIO, Beijing, China] for $40 \mathrm{~min}$ at $37^{\circ} \mathrm{C}$. Finally, the cells were stained by diaminobenzidine counterstained with hematoxylin. The primary antibody was replaced with PBS as a negative control. The median absorbance values of RelA and RelB were determined using image analysis software (Prism; Shanghai, China) after scanning.

Protein determination. The BCA Protein Assay kit (cat. no. P0013C; Beyotime Institute of Biotechnology, Shanghai, China) was used to determine protein concentrations in Caco-2 cells, according to the manufacturer's instructions.

Western blot analysis. Proteins (40 ng) extracted from Caco-2 cells were separated using sodium dodecyl sulfate-polyacrylamide gel electrophoresis and transferred to polyvinylidene fluoride membranes. The membranes were then incubated with Tris-buffered saline-Tween-20 containing 5\% skimmed milk for $2 \mathrm{~h}$ at room temperature. The membranes were incubated overnight at $4^{\circ} \mathrm{C}$ with mouse anti-human RelA (1:1,000; cat. no. SAB1404309) and rabbit anti-human RelB (1:1,000; cat. no. SAB4300501) (both from Sigma-Aldrich, Merck KGaA), rabbit anti-human HIF-1 $\alpha$ $(1: 1,000$; cat. no. ab51608) and rabbit anti-human TNF- $\alpha$ (1:1,000; cat. no. ab6671) (both from Abcam, Cambridge, UK), rabbit anti-human ASK1 (1:1,000; cat. no. SAB1306399; Sigma-Aldrich, Merck KGaA), or GAPDH (1:10,000; cat. no. KC-5G5; Kangcheng Bioengineering Co., Shanghai, China), respectively. The membranes were then incubated with the appropriate secondary antibodies (1:5,000; peroxidase-conjugated goat anti-mouse IgG (cat. no. ZB-5305) and peroxidase-conjugated goat anti-rabbit IgG (cat. no. ZB-5301); ZSGB-BIO). Finally, the membranes were incubated with the SuperEnhanced chemiluminescence (Applygen Technologies Inc., Beijing, China) and the images were scanned by $\mathrm{C} 300$ 
A
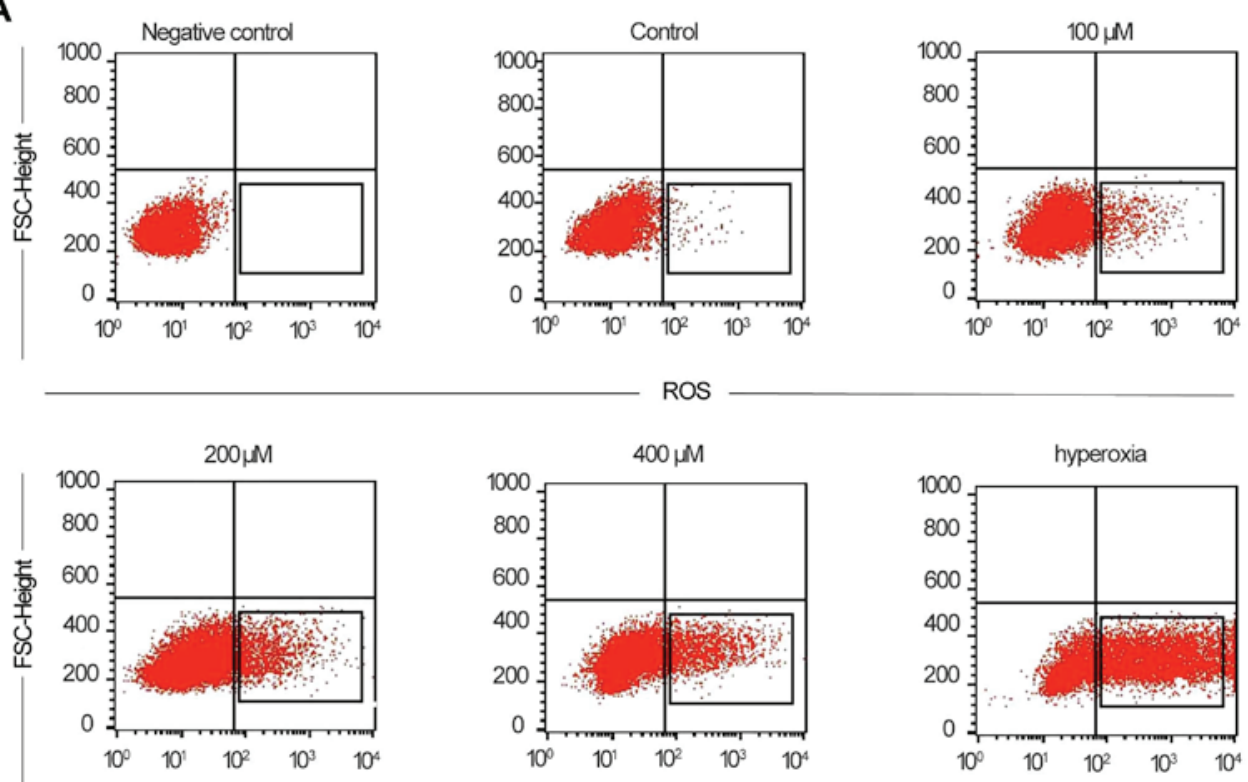

ROS

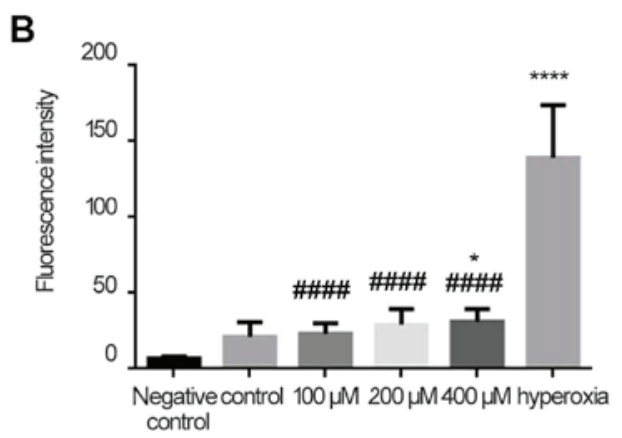

Figure 2. Levels of reactive oxygen species (ROS) in Caco-2 cells in a hyperoxic environment and different concentrations of hydrogen peroxide $\left(\mathrm{H}_{2} \mathrm{O}_{2}\right)$. (A) Flow cytometry scatter diagrams. (B) Levels of ROS in Caco-2 cells. The control group exhibited a small amount of fluorescence. The fluorescence intensity increased with increasing concentrations of $\mathrm{H}_{2} \mathrm{O}_{2}$. In the hyperoxia group, the fluorescence intensity was stronger. The results are presented as mean \pm standard deviation. ${ }^{~} \mathrm{P}<0.05$ compared with the control group; ${ }^{\# \# \#} \mathrm{P}<0.0001$ compared with the $85 \%$ hyperoxia group, unpaired Student's t-test, $\mathrm{n} \geq 6$.

(Azure Biosystems, Inc., Dublin, CA, USA). Image-Pro Plus 6.0 software was used to analyze densitometry for RelA, RelB, HIF-1 $\alpha$, TNF- $\alpha$ and ASK1 protein levels normalized to GAPDH.

Quantitative polymerase chain reaction ( $q P C R$ )analysis. Total RNA was extracted from Caco-2 cells using an RNA Mini kit (RR047A; Takara Biotechnology Co., Ltd., Dalian, China). cDNA was synthesized using 100 ng RNA (RR420A; Takara Biotechnology Co., Ltd.). qPCR was performed using the LightCycler ${ }^{\circledR} 480$ Real-Time PCR system (Roche Applied Science, Mannheim, Germany). The primers for RelA, RelB, HIF-1 $\alpha$, TNF- $\alpha$ and ASK1 were as follows: RelA forward, 5'-GGAGCACAGATACCACCAAGA-3' and reverse, 5'-CGGCAGTCCTTTCCTACAAG-3'; RelB forward, 5'-TGTGGTGAGGATCTGCTTCCAG-3' and reverse, 5'-GGCCCGCTTTCCTTGTTAATTC-3'; HIF-1 $\alpha$ forward, 5'-GCAGCAACGACACAGAAACT-3' and reverse, 5'-AGCGGTGGGTAATGGAGAC-3'; TNF- $\alpha$ forward, 5'-GGCGTGGAGCTGAGAGATAA-3' and reverse, 5'-GTGTGGGTGAGGAGCACAT-3'; ASK1 forward, 5'-TTCACACAAAACGGATGTAACATT-3' and reverse,
5'-CCTAAACAGTTATGGTCACATTTTGG-3'; and GAPDH forward, 5'-GCACCGTCAAGGCTGAGAAC-3' and reverse, 5'-TGGTGAAGACGCCAGTGGA-3'.

The primers and fluorescent probes for RelA, RelB, HIF-1 $\alpha$, TNF- $\alpha$, ASK1 and the internal reference (GAPDH) were purchased from Takara Biotechnology Co., Ltd. The PCR conditions were as follows: A preliminary cycle at $95^{\circ} \mathrm{C}$ for $10 \mathrm{sec}$, followed by 45 cycles at $95^{\circ} \mathrm{C}$ for $5 \mathrm{sec}$ and $60^{\circ} \mathrm{C}$ for $20 \mathrm{sec}$, followed by $1 \mathrm{~min}$ at $60^{\circ} \mathrm{C}$ and $5 \mathrm{sec}$ at $95^{\circ} \mathrm{C}$. The efficiency of amplification for each target gene (GAPDH) was confirmed to be $100 \%$ in the exponential phase of PCR. The mRNA levels were normalized to GADPH mRNA according to the following formula: Active levels of pIgR mRNA = $2^{-\left(\mathrm{Ct}_{\mathrm{pIgR}}-\mathrm{Ct}_{\mathrm{GAPDH}}\right)} \times 100 \%$. The levels of mRNA in the Caco-2 cells exposed to hyperoxia were compared with those of the control group.

Statistical analysis. For each experiment, at least 6 generations of each group were tested. The data from all groups were reported as the means \pm standard deviations. The t-test was used to determine significant differences between treatment groups. $\mathrm{P}<0.05$ was considered to indicate a statistically significant difference. 
A
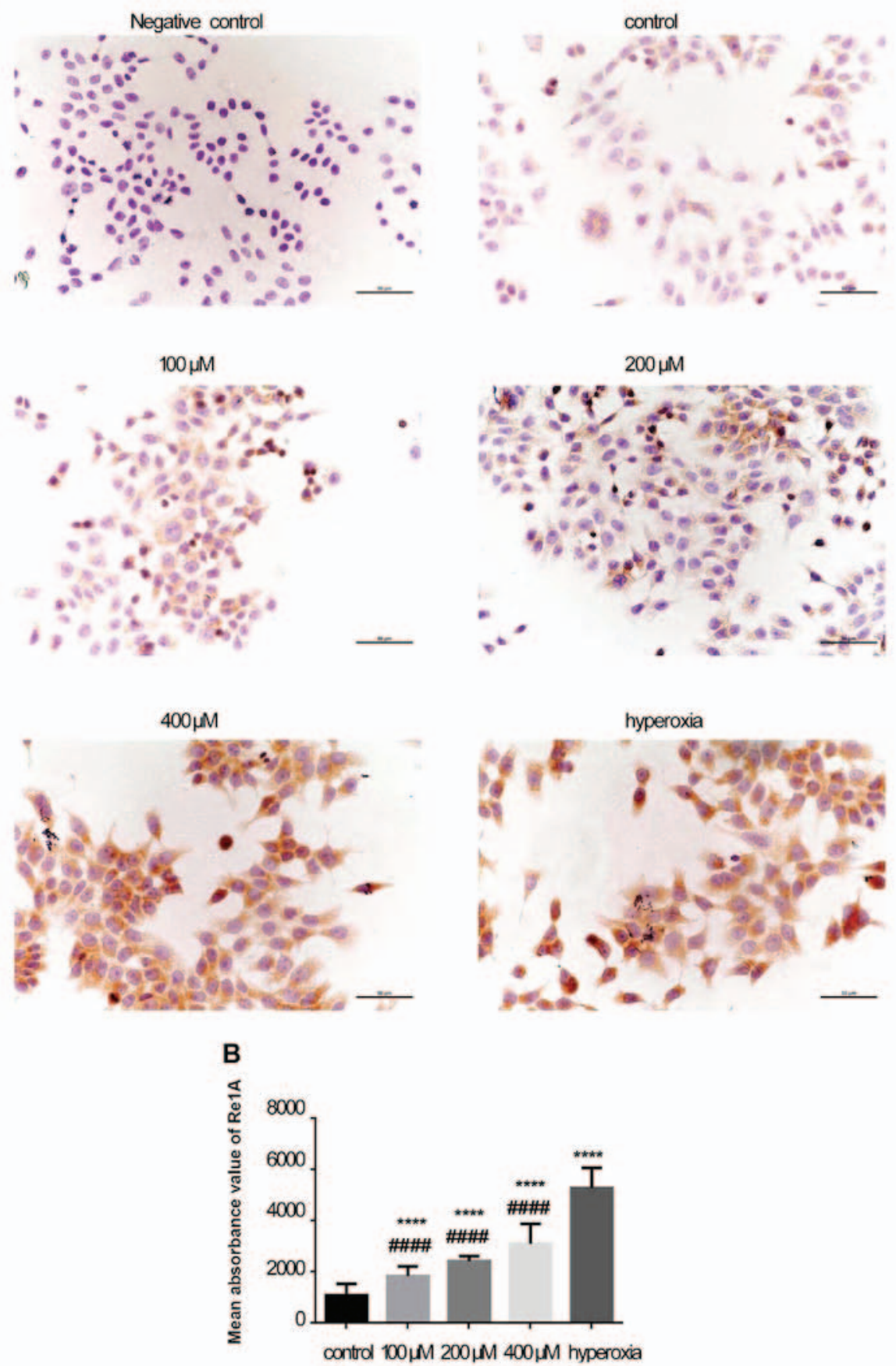

Figure 3. RelA immunochemistry staining of Caco-2 cells treated by hyperoxia and hydrogen peroxide $\left(\mathrm{H}_{2} \mathrm{O}_{2}\right)$. (A) RelA staining. Magnification, $\mathrm{x} 400$. (B) Integrated optical density of RelA. In the control group, RelA staining was located in the cytoplasm. In the $\mathrm{H}_{2} \mathrm{O}_{2}$ and hyperoxia group,s RelA staining was observed in the cytoplasm and nucleus. Compared with the control group, the integrated optical density of RelA was increased in the $\mathrm{H}_{2} \mathrm{O}_{2}$ group and

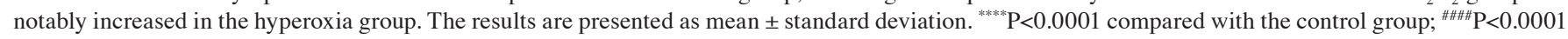
compared with the hyperoxia group, unpaired Student's t-test, $\mathrm{n} \geq 6$.

\section{Results}

Cell survival. The cytotoxic effects of $\mathrm{H}_{2} \mathrm{O}_{2}$ are often attributed to ROS release. We investigated the cytotoxicity of $\mathrm{H}_{2} \mathrm{O}_{2}$ in Caco-2 cells. As shown in Fig. 1, the survival rates of cells exposed to $100 \mu \mathrm{M} \mathrm{H}_{2} \mathrm{O}_{2}(\mathrm{P}<0.01), 200 \mu \mathrm{M} \mathrm{H}_{2} \mathrm{O}_{2}(\mathrm{P}<0.0001)$, $400 \mu \mathrm{M} \mathrm{H}_{2} \mathrm{O}_{2}(\mathrm{P}<0.0001)$, and hyperoxia $(\mathrm{P}<0.0001)$, were significantly lower compared with the control group. However, the survival rates of the $100 \mu \mathrm{M} \mathrm{H}_{2} \mathrm{O}_{2}(\mathrm{P}<0.0001), 200 \mu \mathrm{M}$ $\mathrm{H}_{2} \mathrm{O}_{2}(\mathrm{P}<0.0001)$, and $400 \mu \mathrm{M} \mathrm{H}_{2} \mathrm{O}_{2}(\mathrm{P}<0.0001)$ groups were higher compared with the hyperoxia group. These findings indicate that ROS generation may be responsible for cell injury during hyperoxia.

ROS detection in Caco-2 cells. As shown in Fig. 2A, there was no fluorescence in the negative control, whereas the control group exhibited a small amount of fluorescence. The fluorescence intensity increased with increasing concentrations of $\mathrm{H}_{2} \mathrm{O}_{2}$. In the hyperoxia group, the fluorescence intensity was stronger, and significantly higher compared with that in the 
A

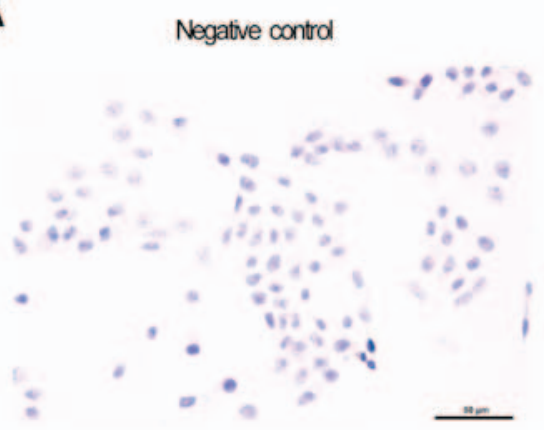

$100 \mu \mathrm{M}$

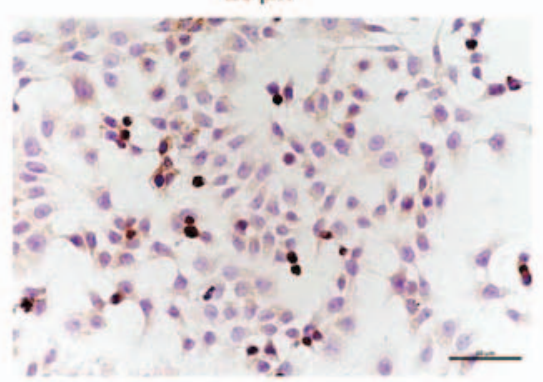

$400 \mu \mathrm{M}$

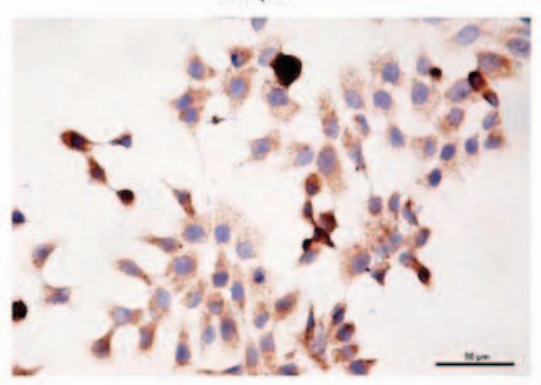

control

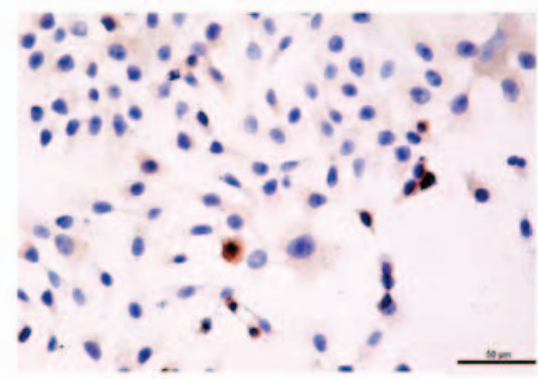

$200 \mu \mathrm{M}$

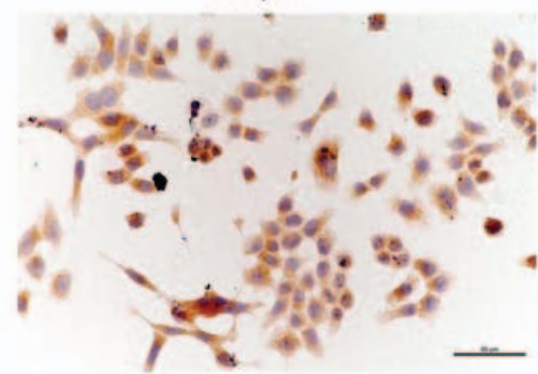

hyperoxia

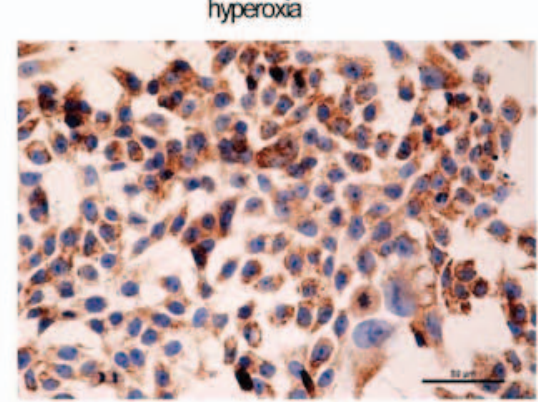

B

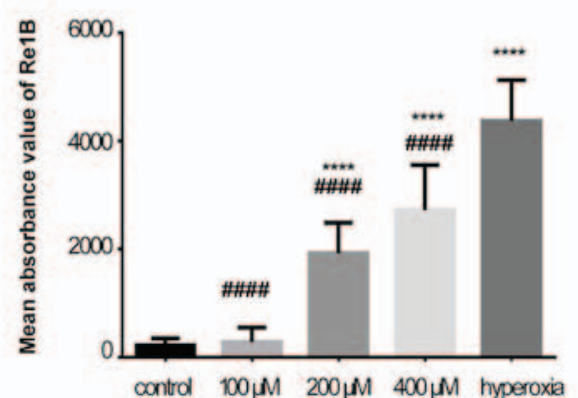

Figure 4. RelB immunochemistry staining of Caco-2 cells treated by hyperoxia and hydrogen peroxide $\left(\mathrm{H}_{2} \mathrm{O}_{2}\right)$. (A) RelB staining. Magnification, $\mathrm{x} 400$. (B) Integrated optical density of RelB. In the control group, RelB staining was observed in the cytoplasm. In the $\mathrm{H}_{2} \mathrm{O}_{2}$ and hyperoxia groups, RelB staining was observed in the cytoplasm and nucleus. Compared with the control group, the integrated optical density of RelB was increased in the $\mathrm{H}_{2} \mathrm{O}_{2}$ group and notably increased in the hyperoxia group. The results are presented as mean \pm standard deviation. ${ }^{* * * *} \mathrm{P}<0.0001$ compared with the control group; ${ }^{\# \# \# \#} \mathrm{P}<0.0001$ compared with the hyperoxia group, unpaired Student's t-test, $\mathrm{n} \geq 6$.

$\mathrm{H}_{2} \mathrm{O}_{2}(\mathrm{P}<0.0001)$ and control $(\mathrm{P}<0.0001)$ groups $($ Fig. 2B). Therefore, it was initially concluded that Caco-2 cells produced more ROS under hyperoxic conditions rather than in a normal environment.

Immunohistochemical staining of RelA and RelB. As shown in Figs. 3A and 4A, RelA and RelB staining was mostly localized in the cytoplasm in the control group. In the $\mathrm{H}_{2} \mathrm{O}_{2}$ and hyperoxia groups, RelA and RelB staining was observed in the cytoplasm and nucleus. The expression of RelA was higher in the $100 \mu \mathrm{M} \mathrm{H}_{2} \mathrm{O}_{2}(\mathrm{P}<0.0001), 200 \mu \mathrm{M} \mathrm{H}_{2} \mathrm{O}_{2}(\mathrm{P}<0.0001)$, and $400 \mu \mathrm{M} \mathrm{H}_{2} \mathrm{O}_{2}(\mathrm{P}<0.0001)$ groups compared with the control group (Fig. 3B). The expression of RelB was higher only in the $200 \mu \mathrm{M} \mathrm{H}_{2} \mathrm{O}_{2}(\mathrm{P}<0.0001)$ and $400 \mu \mathrm{M} \mathrm{H}_{2} \mathrm{O}_{2}(\mathrm{P}<0.0001)$ groups (Fig. 4B). In the hyperoxia group, the morphology of the Caco-2 cells changed and the expression of RelA and RelB was higher $(\mathrm{P}<0.0001)$ compared with that in the control and $\mathrm{H}_{2} \mathrm{O}_{2}$ groups. 
A

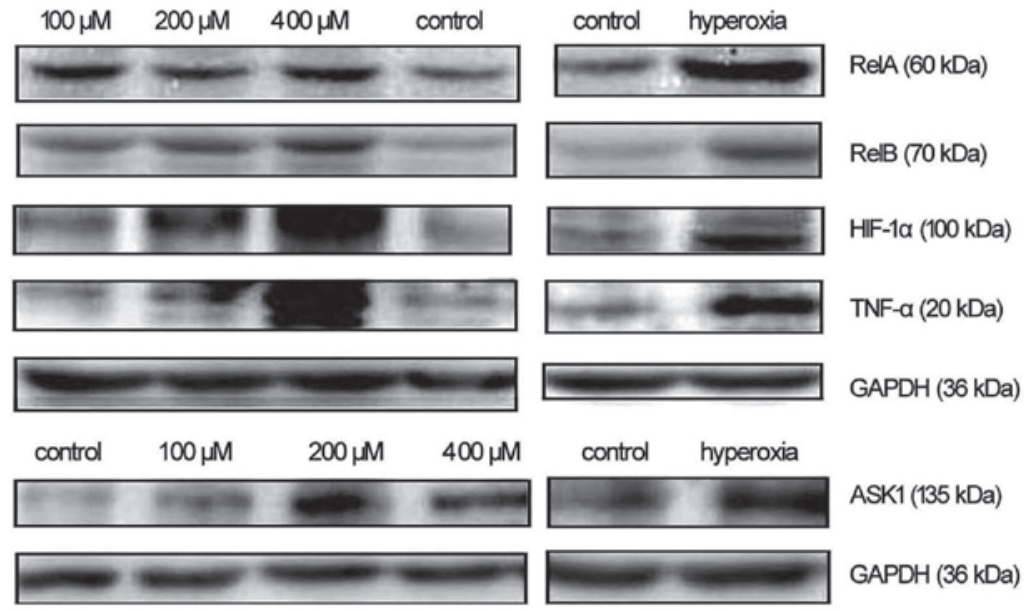

B
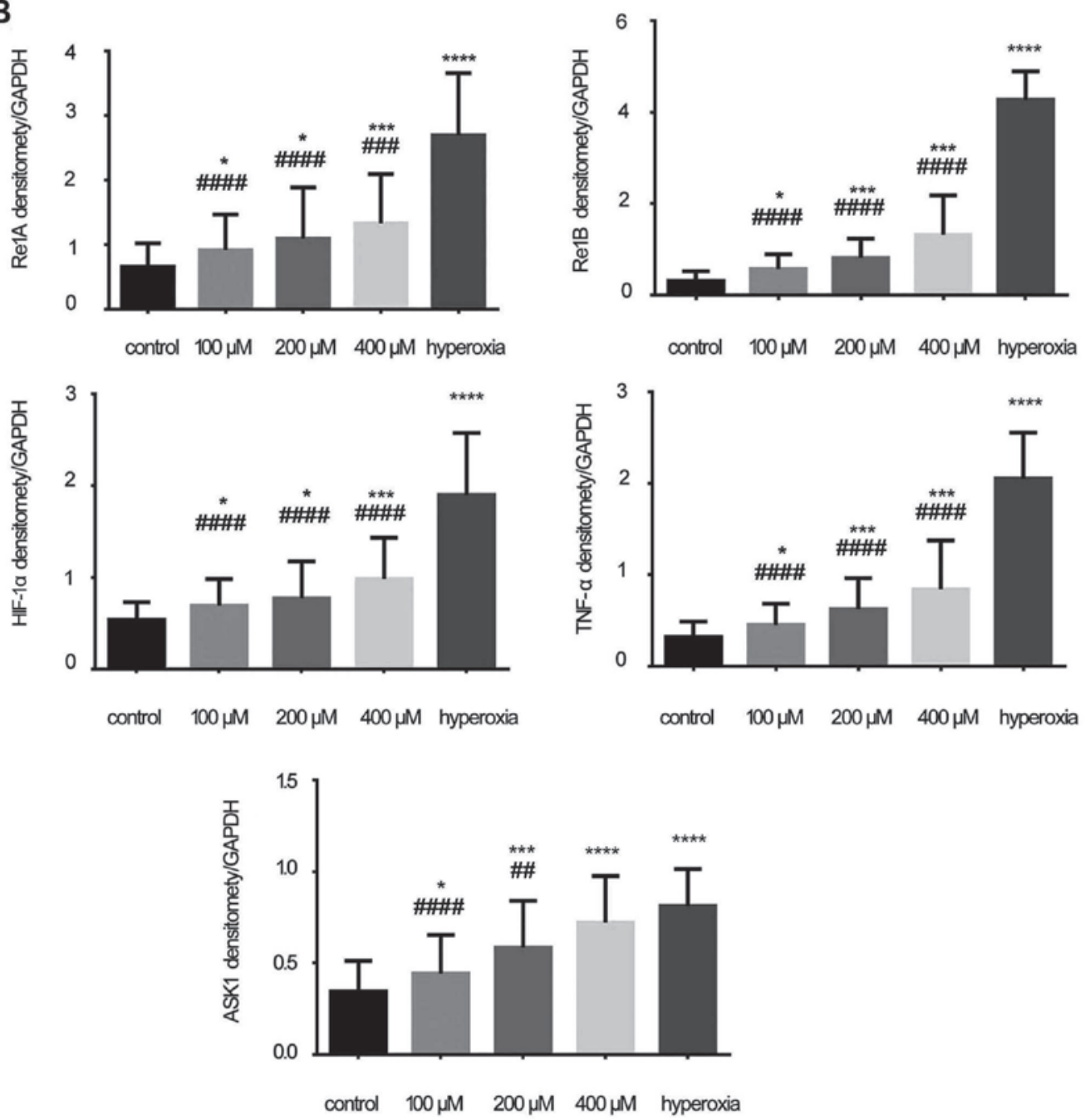

Figure 5. Expression of RelA, RelB, hypoxia-inducible factor-1 $\alpha$ (HIF-1 $\alpha$ ), tumor necrosis factor- $\alpha$ (TNF- $\alpha$ ) and apoptosis signal-regulating kinase 1 (ASK1) proteins . (A) The expression of RelA (60 kDa), RelB (70 kDa), HIF-1 $\alpha$ (100 kDa), TNF- $\alpha$ (20 kDa) and ASK1 (135 kDa). (B) Densitometric analysis of RelA, RelB, HIF-1 $\alpha$, TNF- $\alpha$ and ASK1. In the hydrogen peroxide $\left(\mathrm{H}_{2} \mathrm{O}_{2}\right)$ group, expression of these proteins was higher compared with the control group, while in the hyperoxia group the proteins expression of RelA, RelB, HIF- $1 \alpha$, TNF- $\alpha$ and ASK1 were significantly increased. The results were presented as mean \pm standard deviation. ${ }^{*} \mathrm{P}<0.05$, ${ }^{* * * *} \mathrm{P}<0.001$ and ${ }^{* * * *} \mathrm{P}<0.0001$ compared with the control group; ${ }^{\# \# \#} \mathrm{P}<0.001$ and ${ }^{\# \# \#} \mathrm{P}<0.0001$ compared with the hyperoxia group, unpaired Student's $\mathrm{t}-\mathrm{test}, \mathrm{n} \geq 6$.

Protein expression of RelA, RelB, HIF-1 $\alpha, T N F-\alpha$ and ASK1. The protein expressions of RelA (60 kDa), RelB (70 kDa), HIF-1 $\alpha$ (100 kDa), TNF- $\alpha$ (20 kDa) and ASK1 (135 kDa) were measured (Fig. 5A). The protein expressions of RelA, RelB, HIF-1 $\alpha$, TNF- $\alpha$ and ASK1 increased with increasing concentrations of $\mathrm{H}_{2} \mathrm{O}_{2}$; their levels in the hyperoxia group 

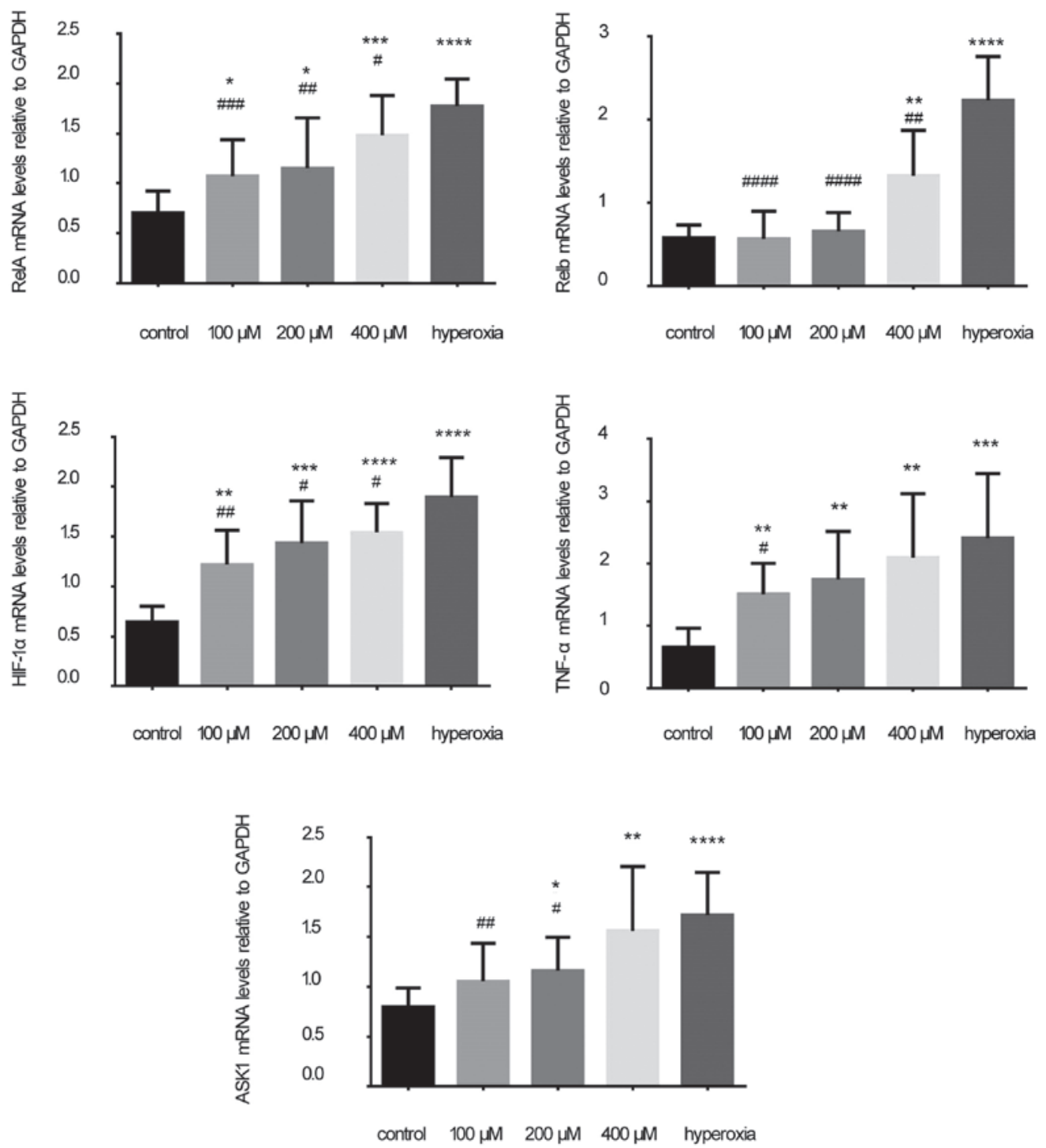

Figure 6. RelA, RelB, hypoxia-inducible factor-1 $\alpha$ (HIF-1 $\alpha$ ), tumor necrosis factor- $\alpha$ (TNF- $\alpha$ ) and apoptosis signal-regulating kinase 1 (ASK1) mRNA levels. The levels of RelA, RelB, HIF-1 $\alpha$, TNF- $\alpha$ and ASK1 mRNAs from the hydrogen peroxide $\left(\mathrm{H}_{2} \mathrm{O}_{2}\right)$ groups and hyperoxia group were significantly increased compared with the control group. The results are presented as mean \pm standard deviation. ${ }^{*} \mathrm{P}<0.05,{ }^{* * * *} \mathrm{P}<0.001$ and ${ }^{* * * * *} \mathrm{P}<0.0001$ compared with the control group; ${ }^{\#} \mathrm{P}<0.05,{ }^{\# \#} \mathrm{P}<0.01$ and ${ }^{\# \# \# \#} \mathrm{P}<0.0001$ compared with the hyperoxia group, unpaired Student's t-test, $\mathrm{n} \geq 6$.

were higher compared with those in the $\mathrm{H}_{2} \mathrm{O}_{2}$ and control groups. Densitometry analysis (RelA, RelB, HIF-1 $\alpha$, TNF- $\alpha$ and ASK1 densitomety/GAPDH densitomety) revealed that the intensity of all these proteins in the hyperoxia group was significantly higher compared with that in the control and $\mathrm{H}_{2} \mathrm{O}_{2}$ groups $(\mathrm{P}<0.05$; Fig. 5B).

$m R N A$ levels of RelA, RelB, HIF-1 $\alpha, T N F-\alpha$ and ASK1. In the hyperoxia group, the mRNA levels of RelA, RelB, HIF-1 $\alpha$, TNF- $\alpha$ and ASK1 were significantly increased than in the control and $\mathrm{H}_{2} \mathrm{O}_{2}$ groups $(\mathrm{P}<0.001$; Fig. 6). The mRNA levels of RelA, RelB, HIF- $1 \alpha$, TNF- $\alpha$ and ASK1 also increased with increasing concentrations of $\mathrm{H}_{2} \mathrm{O}_{2}(\mathrm{P}<0.01$; Fig. 6).

\section{Discussion}

Cells are continuously exposed to ROS, which are generated by aerobic metabolism. Excessive generation of ROS causes severe damage to cells in the form of oxidative stress (17). ROS are byproducts of oxygen metabolism, which plays a crucial role in cell signaling and in maintaining the balance of the organism (18). In complex biological systems, physiologically produced ROS act as second messenger signals that affect cell proliferation and differentiation (19). ROS play an important role as signaling intermediates that induce a variety of cellular responses, such as proliferation, differentiation, senescence and apoptosis (17). As the levels of ROS increase, the rate of apoptosis gradually increases (20). ROS include superoxide radicals, $\mathrm{H}_{2} \mathrm{O}_{2}$, hydroperoxyl radicals and hydroxyl radicals. $\mathrm{H}_{2} \mathrm{O}_{2}$ significantly increases free radicals in the cells, resulting in critical DNA damage (7), and $\mathrm{H}_{2} \mathrm{O}_{2}$-induced oxidative stress increases cell apoptosis (21). During normal metabolism, ROS signal cells to stimulate proliferation or to induce cellular damage, depending on their concentration (22).

In the present study, the results of the MTT assay demonstrated that the amount of apoptotic cells significantly increased during hyperoxia and at higher doses of $\mathrm{H}_{2} \mathrm{O}_{2}$. The results of flow cytometry revealed that the levels of ROS under 
conditions of hyperoxia were significantly higher compared with those under normal conditions. Initially, on the basis of these findings, it was concluded that hyperoxia may stimulate organs to produce more ROS (23). Hyperoxia may also cause oxidative damage and induce production of ROS in the mitochondria and expression of antioxidant proteins (24), and may also increase the antioxidant response to ROS (25). Therefore, increasing levels of ROS is the first step in the series of reactions that constitute intestinal inflammation (18). Hyperoxia-induced epithelial disruption is associated with tight junction weakening and the development of a pro-inflammatory environment (3).

ROS induce the production of cytokines during inflammation (26). Subsequently, TNF- $\alpha$ may lead to cell damage by inducing the production of intracellular mitochondrial ROS, thereby increasing intestinal inflammation and damage (27). High expression of TNF- $\alpha$ in intestinal epithelial cells suggests that TNF- $\alpha$ levels may be indicative of intestinal damage (27). Therefore, TNF- $\alpha$ expression was detected in the intestinal epithelium. The results revealed that the damage to the intestinal epithelial cells that was induced by $\mathrm{H}_{2} \mathrm{O}_{2}$ or hyperoxia increased the expression of TNF- $\alpha$ at the protein and gene levels. TNF- $\alpha$ activates MLK3 and leads to JNK activation in vivo (28). As a member of the MAPK family, ASK1 is present in several physiological and pathological processes. ASK1 is required for apoptosis induced by oxidative stress and TNF (29). In normal cells, activation of ASK1 is strictly controlled by phosphorylation and dephosphorylation of serine/threonine. Since it may be activated by several stress and inflammatory factors, the overexpression of ASK1 may induce cell apoptosis through the MAPK signaling pathway, and ASK1 is activated in cells treated with TNF- $\alpha(30,31)$. ROS also directly or indirectly affect signaling molecules, such as protein kinases (MAPK), which cause oxidative damage to organs $(1,32)$. During oxidative stress, $\mathrm{H}_{2} \mathrm{O}_{2}$ catalyzes the phosphorylation of ASK1, and then activates the downstream JNK/p38 pathway, promoting cell apoptosis (33). Therefore, the role of ASK1 in the MAPK family was specifically investigated. Our results demonstrated that, with the increased oxidative stress induced by hyperoxia, the expression of ASK1 significantly increased at the protein and gene levels.

TNF- $\alpha$ mediates activation of the NF- $\kappa$ B survival pathway in the cytoplasm (34). The NF- $\kappa$ B pathway regulates genes encoding acute reactive proteins, cytokines, cell adhesion molecules, and immune regulatory molecules in inflammation. $\mathrm{NF}-\kappa \mathrm{B}$ is an important signaling molecule, and it is involved in physiological responses induced by hyperoxia in different cell types and tissues (35). $\mathrm{NF}-\kappa \mathrm{B}$ may also regulate inflammatory response and epithelial cell damage or death (36). It has also been reported that the activation of oxidative stress and $\mathrm{NF}-\kappa \mathrm{B}$ plays an important role in the pathogenesis of inflammatory bowel disease (IBD) (37). In the present study, RelA and RelB expression in the NF- $\kappa \mathrm{B}$ signaling pathway were significantly increased at both the protein and gene levels during hyperoxia and at higher doses of $\mathrm{H}_{2} \mathrm{O}_{2}$. This proves that intestinal inflammation may occur in hyperoxia and that ROS play an important role in inflammation induced by hyperoxia.

$\mathrm{NF}-\kappa \mathrm{B}$ is involved in stimulating HIF- $1 \alpha$ mRNA expression. There is significant evidence on the need for an intact $\mathrm{NF}-\kappa \mathrm{B}$ pathway for proper oxygen- and ligand-induced HIF activity (38). HIF-1 $\alpha$ is key to the pathogenesis of IBD, and the role of HIF-1 $\alpha$ in immune cells is becoming increasingly important (39). Therefore, the protein and mRNA levels of HIF-1 $\alpha$ were measured. The results demonstrated that $85 \%$ hyperoxia and high concentrations of $\mathrm{H}_{2} \mathrm{O}_{2}$ exerted similar effects in terms of activating the HIF signaling pathway. This proves that ROS play an important role during hyperoxia.

In conclusion, intestinal epithelial cells were destroyed and the levels of ROS increased during hyperoxia. Thus, ROS may play an important role in intestinal injury in a hyperoxic environment. In the future, further research focusing on the intestinal mechanisms of hyperoxic injury may reveal an even more important role of ROS. Novel strategies for treating hyperoxia-induced intestinal injury must also be investigated.

\section{Acknowledgements}

This study was supported by the National Natural Science Foundation of China (grant nos. 30871158 and 81170604) and the Outstanding Scientific Fund of Shengjing Hospital.

\section{References}

1. Zhao HW, Ali SS and Haddad GG: Does hyperoxia selection cause adaptive alterations of mitochondrial electron transport chain activity leading to a reduction of superoxide production? Antioxid Redox Signal 16: 1071-1076, 2012.

2. Torbati D, Tan GH, Smith S, Frazier KS, Gelvez J, Fakioglu H and Totapally BR: Multiple-organ effect of normobaric hyperoxia in neonatal rats. J Crit Care 21: 85-93, 2006

3. Al-Shmgani HS, Moate RM, Macnaughton PD, Sneyd JR and Moody AJ: Effects of hyperoxia on the permeability of 16HBE14o- cell monolayers - the protective role of antioxidant vitamins E and C. FEBS J 280: 4512-4521, 2013.

4. Hong Y, Sun LI, Sun R, Chen H, Yu Y and Xie K: Combination therapy of molecular hydrogen and hyperoxia improves survival rate and organ damage in a zymosan-induced generalized inflammation model. Exp Ther Med 11: 2590-2596, 2016.

5. Carnesecchi S, Deffert C, Pagano A, Garrido-Urbani S, Métrailler-Ruchonnet I, Schäppi M, Donati Y, Matthay MA, Krause KH and Barazzone Argiroffo C: NADPH oxidase-1 plays a crucial role in hyperoxia-induced acute lung injury in mice. Am J Respir Crit Care Med 180: 972-981, 2009.

6. Niethammer P, Grabher C, Look AT and Mitchison TJ: A tissue-scale gradient of hydrogen peroxide mediates rapid wound detection in zebrafish. Nature 459: 996-999, 2009.

7. Cai X, Chen X, Wang X, Xu C, Guo Q, Zhu L, Zhu S and Xu J: Pre-protective effect of lipoic acid on injury induced by $\mathrm{H}_{2} \mathrm{O}_{2}$ in IPEC-J2 cells. Mol Cell Biochem 378: 73-81, 2013.

8. Oncel MY, Yurttutan S, Alyamac Dizdar E, Gokce IK, Gonul II, Topal T, Canpolat FE and Dilmen U: Beneficial effect of etanercept on hyperoxic lung injury model in neonatal rats. J Invest Surg 29: 1-5, 2016

9. Matsuzawa A and Ichijo H: Redox control of cell fate by MAP kinase: physiological roles of ASK1-MAP kinase pathway in stress signaling. Biochim Biophys Acta 1780: 1325-1336, 2008.

10. Vermeulen L, De Wilde G, Van Damme P, Vanden Berghe W and Haegeman G: Transcriptional activation of the NF-kappaB p65 subunit by mitogen- and stress-activated protein kinase-1 (MSK1). EMBO J 22: 1313-1324, 2003.

11. Bhatia HS, Baron J, Hagl S, Eckert GP and Fiebich BL: Rice bran derivatives alleviate microglia activation: possible involvement of MAPK pathway. J Neuroinflammation 13: 148, 2016.

12. Bentovim L, Amarilio R and Zelzer E: HIF1 $\alpha$ is a central regulator of collagen hydroxylation and secretion under hypoxia during bone development. Development 139: 4473-4483, 2012.

13. Baylor AE, Diebel LN, Liberati DM, Dulchavsky SA, Diglio CA and Brown WJ: The effects of varying oxygen conditions and immunoglobulin A on barrier defense to bacterial invasion. Am Surg 69: 231-237, 2003.

14. Diebel LN, Liberati DM, Brown WJ, Dulchavsky SA, Painter TM, Diglio CA and Montgomery PC: Secretory immunoglobulin A blocks hypoxia-augmented bacterial passage across Madin-Darby canine kidney cell monolayers. J Trauma 43: 759-763, 1997. 
15. Diebel LN, Liberati DM, Dulchavsky SA, Diglio CA and Brown WJ: Synergistic effect of hyperoxia and immunoglobulin A on mucosal barrier defense. J Trauma 46: 374-378, 1999.

16. Liu DY and Li JJ: Effect of hyperoxia on the intestinal IgA secretory component in neonatal rats and on intestinal epithelial cells in vitro. Braz J Med Biol Res 43: 1034-1041, 2010.

17. Fujisawa T, Takeda $\mathrm{K}$ and Ichijo $\mathrm{H}$ : ASK family proteins in stress response and disease. Mol Biotechnol 37: 13-18, 2007.

18. Ruh J, Vogel F, Schmidt E, Werner M, Klar E, Secchi A, Gebhard MM, Glaser F and Herfarth C: Effects of hydrogen peroxide scavenger Catalase on villous microcirculation in the rat small intestine in a model of inflammatory bowel disease. Microvasc Res 59: 329-337, 2000.

19. Jones RM, Luo L, Ardita CS, Richardson AN, Kwon YM, Mercante JW, Alam A, Gates CL, Wu H, Swanson PA, et al: Symbiotic lactobacilli stimulate gut epithelial proliferation via Nox-mediated generation of reactive oxygen species. EMBO J 32: 3017-3028, 2013.

20. Ma Z, Moruzzi N, Catrina SB, Grill V and Björklund A: Hyperoxia inhibits glucose-induced insulin secretion and mitochondrial metabolism in rat pancreatic islets. Biochem Biophys Res Commun 443: 223-228, 2014

21. Jin S, Ray RM and Johnson LR: TNF-alpha/cycloheximide-induced apoptosis in intestinal epithelial cells requires Rac1-regulated reactive oxygen species. Am J Physiol Gastrointest Liver Physiol 294: G928-G937, 2008.

22. Kajino-Sakamoto R, Omori E, Nighot PK, Blikslager AT, Matsumoto K and Ninomiya-Tsuji J: TGF-beta-activated kinase 1 signaling maintains intestinal integrity by preventing accumulation of reactive oxygen species in the intestinal epithelium. J Immunol 185: 4729-4737, 2010.

23. Camporesi EM and Bosco G: Hyperbaric oxygen pretreatment and preconditioning. Undersea Hyperb Med 41: 259-263, 2014

24. Klimova TA, Bell EL, Shroff EH, Weinberg FD, Snyder CM, Dimri GP, Schumacker PT, Budinger GR and Chandel NS: Hyperoxia-induced premature senescence requires $\mathrm{p} 53$ and $\mathrm{pRb}$, but not mitochondrial matrix ROS. FASEB J 23: 783-794, 2009.

25. Steer JH, Mann TS, Lo SZ, Inglis JJ, Yap HS, Henry PJ and Joyce DA: Early induction of uncoupling protein-2 in pulmonary macrophages in hyperoxia-associated lung injury. Inhal Toxicol 25: 544-552, 2013.

26. Kina S, Nakasone T, Takemoto H, Matayoshi A, Makishi S, Sunagawa N, Liang F, Phonaphonh T and Sunakawa H: Regulation of chemokine production via oxidative pathway in HeLa cells. Mediators Inflamm 2009: 183760, 2009.

27. Baregamian N, Song J, Bailey CE, Papaconstantinou J, Evers BM and Chung DH: Tumor necrosis factor-alpha and apoptosis signal-regulating kinase 1 control reactive oxygen species release, mitochondrial autophagy, and c-Jun N-terminal kinase/p38 phosphorylation during necrotizing enterocolitis. Oxid Med Cell Longev 2: 297-306, 2009.
28. Sathyanarayana P, Barthwal MK, Kundu CN, Lane ME, Bergmann A, Tzivion G and Rana A: Activation of the Drosophila MLK by ceramide reveals TNF-alpha and ceramide as agonists of mammalian MLK3. Mol Cell 10: 1527-1533, 2002.

29. Takeda K, Matsuzawa A, Nishitoh H and Ichijo H: Roles of MAPKKK ASK1 in stress-induced cell death. Cell Struct Funct 28: 23-29, 2003.

30. Ichijo H, Nishida E, Irie K, ten Dijke P, Saitoh M, Moriguchi T, Takagi M, Matsumoto K, Miyazono K and Gotoh Y: Induction of apoptosis by ASK1, a mammalian MAPKKK that activates SAPK/JNK and p38 signaling pathways. Science 275: 90-94, 1997.

31. Nakagawa $\mathrm{H}$ and Maeda S: Inflammation- and stress-related signaling pathways in hepatocarcinogenesis. World J Gastroenterol 18: 4071-4081, 2012.

32. Gore A, Muralidhar M, Espey MG, Degenhardt K and Mantell LL: Hyperoxia sensing: from molecular mechanisms to significance in disease. J Immunotoxicol 7: 239-254, 2010.

33. Subramanian RR, Zhang H, Wang H, Ichijo H, Miyashita $T$ and $\mathrm{Fu} \mathrm{H}$ : Interaction of apoptosis signal-regulating kinase 1 with isoforms of 14-3-3 proteins. Exp Cell Res 294: 581-591, 2004

34. Chun JN, Choi B, Lee KW, Lee DJ, Kang DH, Lee JY, Song IS, Kim HI, Lee SH, Kim HS, et al: Cytosolic Hsp60 is involved in the NF-kappaB-dependent survival of cancer cells via IKK regulation. PLoS One 5: e9422, 2010.

35. Zara S, De Colli M, Rapino M, Di Valerio V, Marconi GD, Cataldi A, Macchi V, De Caro R and Porzionato A: NF- $\kappa$ B involvement in hyperoxia-induced myocardial damage in newborn rat hearts. Histochem Cell Biol 140: 575-583, 2013.

36. Zaher TE, Miller EJ, Morrow DM, Javdan M and Mantell LL: Hyperoxia-induced signal transduction pathways in pulmonary epithelial cells. Free Radic Biol Med 42: 897-908, 2007.

37. Babu D, Lee JS, Park SY, Thapa D, Choi MK, Kim AR, Park YJ and Kim JA: Involvement of NF-kappaB in the inhibitory actions of Platycarya strobilacea on the TNF-alpha-induced monocyte adhesion to colon epithelial cells and chemokine expression. Arch Pharm Res 31: 727-735, 2008.

38. Cummins EP, Keogh CE, Crean D and Taylor CT: The role of HIF in immunity and inflammation. Mol Aspects Med 47-48: 24-34, 2016.

39. Flück K and Fandrey J: Oxygen sensing in intestinal mucosal inflammation. Pflugers Arch 468: 77-84, 2016.

This work is licensed under a Creative Commons Attribution-NonCommercial-NoDerivatives 4.0 International (CC BY-NC-ND 4.0) License. 